\title{
Avanços tecnológicos em hematologia laboratorial
}

Paulo C. NaOum

\begin{abstract}
O recente avanço científico e tecnológico direcionado à identificação imunobematológica de produtos celulares (ex.: citocinas, interleucinas, interferons, entre outros) sintetizados por determinadas células sanguíneas, bem como na identificação de antígenos de membrana de leucócitos e células progenitoras bematopoiéticas, promoveram excepcional desenvolvimento no diagnóstico laboratorial de diversas doenças hematológicas. Somam-se a esse fato as aplicações das técnicas de biologia molecular que se tornam cada vez mais instrumentos laboratoriais de grande definição no diagnóstico e na prevenção de doenças hematológicas, notadamente aquelas de origem hereditária. $O$ presente artigo teve o objetivo de expor as principais aplicações de novas tecnologias que deverão ser adotadas rapidamente pela moderna hematologia laboratorial, bem como a de sensibilizar os profissionais hematologistas, clinicos e laboratoriais, para a necessidade de se atualizarem numa nova ciência, a dos produtos celulares.

Rev.bras.hematol.hemoter., 2001, 23(2):
\end{abstract}

Palavras-chave: Hematologia, biologia molecular, citocinas

\section{Introdução}

Os principais avanços científicos e tecnológicos são as principais causas de mudanças na prática da moderna hematologia, influindo especialmente no diagnóstico laboratorial e nos procedimentos terapêuticos de algumas patologias com destaques para anemia falciforme, hemofilias e leucemias. O progresso obtido pela imunologia tem alavancado o desenvolvimento do diagnóstico laboratorial de diversas doenças hematológicas mielo e linfoproliferativas, bem como determinando especificidades da fisiologia leucocitária diante das toxicidades de proveniências bacterianas e virais. Essas conquistas ultrapassaram as fronteiras das aplicações laboratoriais e forneceram conhecimentos importantes nos procedimentos terapêuticos $(1,5,8)$.

O crescimento das aplicações tecnológicas que resultaram na automação dos laboratórios, além de produzir maior grau de reprodutibilidade dos resultados de exames e rapidez nas suas determinações, avançou para um grau de especificidade tal que deverá exigir dos médicos e dos profissionais de laboratórios constantes atualizações. Os exemplos mais recentes se baseiam na moderna imunohematologia direcionada à diferenciação das células, em especial dos leucócitos, por meio da identificação de seus antígenos conhecidos por "cluster of differentiation" ou $\mathrm{CD}$, bem como da caracterização funcional

Professor Titular da UNESP de São José do Rio Preto

Coordenador da Academia de Ciência e Tecnologia

Correspondência: Paulo Cesar Naoum

Academia de Ciência e Tecnologia. Rua Bonfá Natale, 1860. 15020-130. São José do Rio Preto. SP

E-mail:a.c.t.@zaz.com.br

Home Page: www.ciencianews.com.br 
das citocinas. Por outro lado, a biologia molecular se torna cada vez mais um instrumento laboratorial de grande definição.

\section{Diferenciação celular ou CD}

Todas as células possuem em suas composições estruturais de membranas proteínas específicas capazes de serem reconhecidas por anticorpos sintetizados em laboratórios - os anticorpos monoclonais. Para os anticorpos monoclonais as proteínas de membrana de células blásticas, linfócitos, monócitos, entre outras, são identificadas como "antígenos celulares". Porém, observou-se que grupos de diferentes anticorpos monoclonais reconheciam o mesmo antígeno celular presente em mais de uma célula, quer fossem normais, malignas ou células de linhagens evolutivas. Esses antígenos de diferenciação celular reconhecidos por grupos de anticorpos monoclonais foram denominados por grupo de diferenciação celular ou CD $(6,7)$. Foram reconhecidos em experimentação laboratorial perto de 170 diferentes tipos de CD, conhecidos por CD1, CD2, CD3, CD4, etc., cujas relações entre as células identificadas e suas funções específicas também foram relacionadas. A tabela 1 mostra a relação entre alguns antígenos CD selecionados com

Tabela 1. Relação entre alguns antígenos CD, células e funções

\begin{tabular}{|c|c|c|}
\hline Antígeno & CD Células & Funções \\
\hline CD1 a,b,c,d & $\begin{array}{l}\text { Timócitos, células dendríticas } \\
\text { Linfócito B (CD1c), células do } \\
\text { epitélio intestinal (CD1d) }\end{array}$ & $\begin{array}{l}\text { Molécula semelhante ao MHC- } \\
\text { classe 1, especializada na } \\
\text { apresentação de antígeno }\end{array}$ \\
\hline $\mathrm{CD} 4$ & $\begin{array}{l}\text { Sub grupo de timócitos, linfócito T } \\
\text { auxiliar e inflamatório, } \\
\text { monócitos e macrófagos }\end{array}$ & $\begin{array}{l}\text { Co-receptor de moléculas } \\
\text { de MHC de classe } 2 \text {. Receptor } \\
\text { para HIV-1 e HIV-2 }\end{array}$ \\
\hline $\mathrm{CD} 8$ & $\begin{array}{l}\text { Sub grupo de timócitos, linfócitos T } \\
\text { citotóxicos }\end{array}$ & $\begin{array}{l}\text { Co-receptor para MHC de } \\
\text { classe } 1\end{array}$ \\
\hline $\mathrm{CD} 9$ & $\begin{array}{l}\text { Linfócito Pré-B, eosinófilos, } \\
\text { basófilos e plaquetas }\end{array}$ & $\begin{array}{l}\text { Possível função na agregação } \\
\text { e ativação das plaquetas }\end{array}$ \\
\hline CD 33 & $\begin{array}{l}\text { Células mielóides } \\
\text { progenitoras e monócitos }\end{array}$ & Desconhecidas \\
\hline CD 34 & $\begin{array}{l}\text { Precursores hematopoiéticos } \\
\text { ou células tronco pluripotencial }\end{array}$ & Ligante para CD $62 \mathrm{~L}$ \\
\hline CD $62 \mathrm{~L}$ & $\begin{array}{l}\text { Linfócitos B e T, monócitos e } \\
\text { NK }\end{array}$ & $\begin{array}{l}\text { Moléculas de adesão de } \\
\text { leucócitos. Participa da } \\
\text { Interação com endotélio }\end{array}$ \\
\hline CD 71 & Leucócitos ativados & Receptor de transferrina \\
\hline CD 166 & $\begin{array}{l}\text { Atividade leucocitária } \\
\text { na adesão de moléculas }\end{array}$ & $\begin{array}{l}\text { Ativação de linfócitos T e B, } \\
\text { eosinófilos, fibroblasto } \\
\text { cels. timicas e endoteliais, e } \\
\text { queratinócitos }\end{array}$ \\
\hline
\end{tabular}


Tabela 2. Relação entre determinantes celulares - CD e subpopulações de células identificadas

\begin{tabular}{|c|c|}
\hline CD & Subpopulações de células identificadas \\
\hline \multicolumn{2}{|l|}{ Linfócito B } \\
\hline CD 10 & Pré-B; Estágio 1 dos timócitos \\
\hline CD 19 & Pré-B; Linfócitos B \\
\hline CD 20 & Maioria dos linfócitos B ; 1⁄2 de Pré-B \\
\hline \multirow[t]{2}{*}{ CD 21} & Maioria dos linfócitos B; do sangue, zona do manto e \\
\hline & folículo primário \\
\hline $\mathrm{CD} 22$ & Maioria dos linfócitos B; $1 / 2$ de Pré-B \\
\hline CD 24 & Ativação de antígenos de linfócitos B \\
\hline CD 38 & Linfócitos B \\
\hline CD 40 & Linfócitos B \\
\hline CD 72 & Linfócitios Pan-B \\
\hline CD 73 & Linfócitos B e sub grupos de células T \\
\hline CD 74 & Linfócitos B e macrófagos \\
\hline $\mathrm{CDw} 75$ & Linfócitos B maduros e sub grupos de células $\mathrm{T}$ \\
\hline CD 76 & Linfócitos B maduros, sub grupos de células T, e PMNs \\
\hline $\mathrm{CDw} 78$ & Linfócitos Pan-B; macrófagos \\
\hline \multicolumn{2}{|c|}{ Linfócitos T } \\
\hline CD 1 & Linfócitos T, células de Langerhans \\
\hline $\mathrm{CD} 2 \mathrm{R}$ & Linfócitos $\mathrm{T}$ ativados \\
\hline $\mathrm{CD} 4$ & Linfócitos T (auxiliar/indutor) \\
\hline $\mathrm{CD} 7$ & Linfócitos T e timócitos \\
\hline CD 8 & Linfócitos T (citotóxico e supressor) \\
\hline CD 27 & Linfócitos T e plasmócitos \\
\hline CD 28 & Linfócitos T citotóxicos - CD 8 \\
\hline \multirow[t]{2}{*}{ CD 34} & Células progenitoras linfóides, centro germinal de \\
\hline & Linfócitos B e plasmócitos, linfócitos T proliferantes \\
\hline CD $45 \mathrm{RA}$ & Linfócitos B, T e NK; monócitos \\
\hline $\mathrm{CD} 45 \mathrm{RO}$ & Linfócitos T de memória, células mielóides \\
\hline \multicolumn{2}{|c|}{ Linfócito NK } \\
\hline CD 2 & Linfócitos T e maioria de NK \\
\hline CD 3 & Linfócitos $\mathrm{T}$ ativados \\
\hline CD 7 & Maioria de linfócitos T e timócitos \\
\hline $\mathrm{CD} 11 \mathrm{~b}$ & Monócitos e linfócitos T \\
\hline CD 16 & Linfócitos NK, alguns linfócitos T e monócitos \\
\hline CD 56 & Linfócitos NK, alguns linfócitos T \\
\hline CD 57 & Linfócitos NK, alguns linfócitos T \\
\hline
\end{tabular}

PMN: polimorfonucleares (em especial os neutrófilos) 


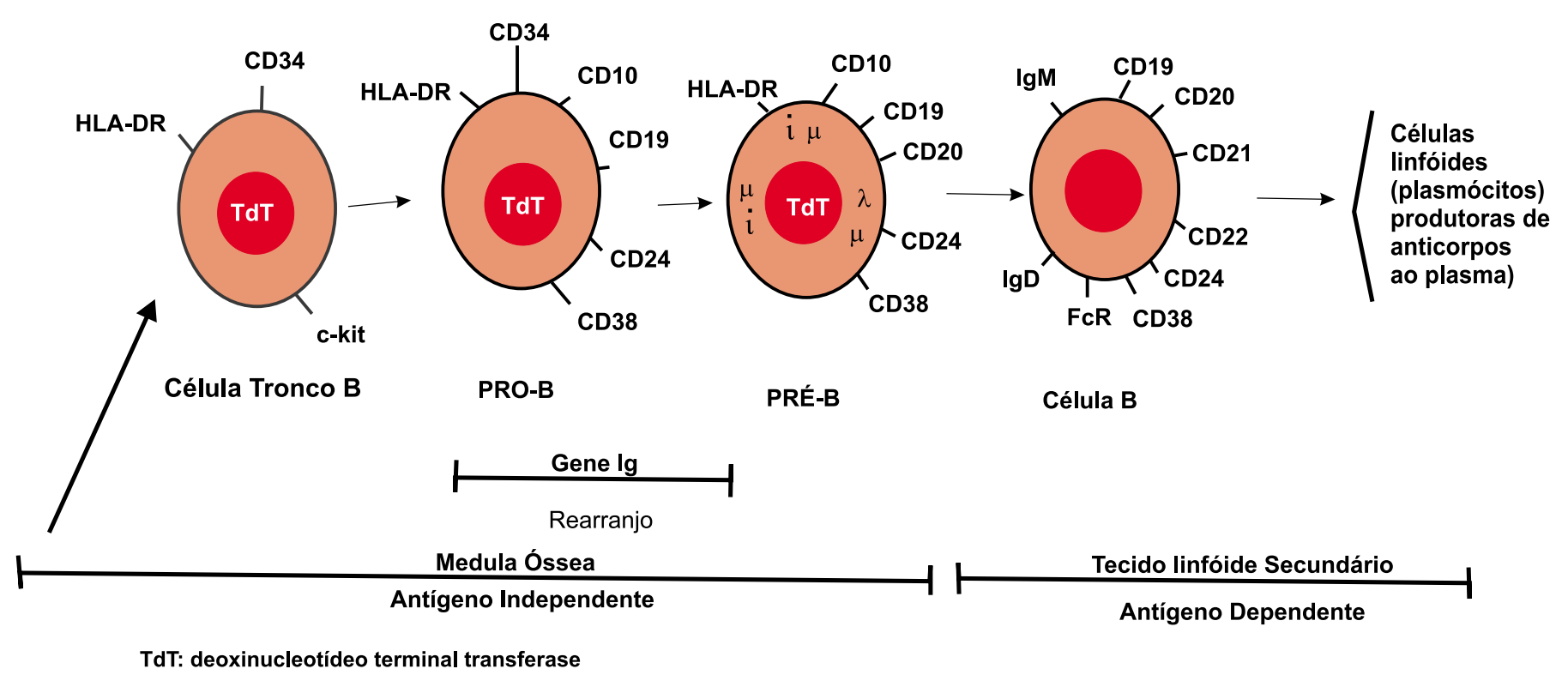

Figura 1a. Exemplo-padrão da expressão deantígenos de superfície durante a maturação de linfócitos B

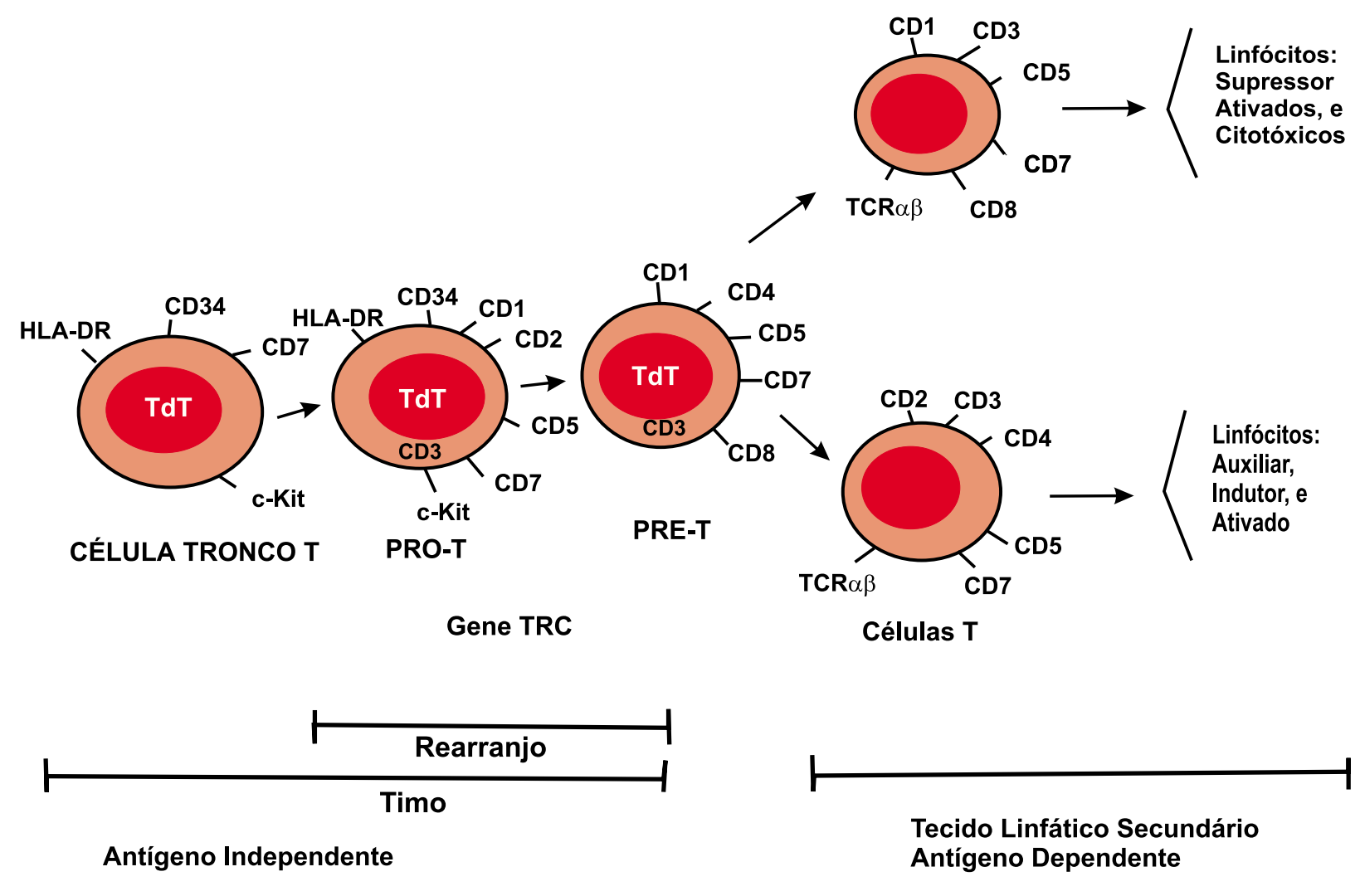

TRC: receptor de antígenos de células T

Figura 1b. Exemplo-padrão da expressão de antígenos de superfície durante a maturação de linfócitos T 
Tabela 3. Marcadores usados para auxiliar o diagnóstico das leucemias agudas e crônicas

\begin{tabular}{l|l}
\hline Leucemia & Marcadores \\
\hline Aguda & \\
\hline LLA comum & \\
\hline LLA "nula" & CD 10, CD 19, Mb-1 (cyt), Tdt (n) \\
\hline LLA Pré-B & CD 19, Mb-1 (cyt), Tdt (n) \\
\hline LLA - T & CD 19, Mb-1 (cyt), IgM (m, cyt) \\
LMA & CD 7, CD 3 (cyt), Tdt (n) \\
\hline LMMA, LMA - Tipo zero & CD 13, CD 33, mieloperoxidase (cyt) \\
\hline LGC em crise blástica & CD 13, CD 33, CD 14, CD 11c \\
\hline LGC em crise linfoblástica & CD 13, CD 33, CD 14, CD 15 \\
Linfoma agudo de células T & Tdt (n) \\
\hline Crônica & CD 3, CD 4 \\
\hline LLC- B & \\
LCC & CD 19, CD 20, CD 5, slg +/- \\
LLP & CD 19, CD 20, TRAP \\
Sezary/micose & CD 19, CD 20, slg ++ \\
LLC - T & CD 3, CD 4 \\
\hline
\end{tabular}

LLA: leucemia linfóide aguda; LMA: leucemia mielóide aguda; LMMA: leucemia mielomonocítica aguda; LGC: leucemia granulocítica crônica; LLC: leucemia linfocítica crônica; LLP: leucemia prólinfocítica; Sezary: síndrome de Sezary e micose fungóide relacionadas a Linfoma de células T; LCC: leucemia das células cabeludas; TRAP: fosfatase ácida resistente a tartarato; cyt: citoplasmático; slg: imunoglobulina de superficie de membrana; Tdt: transferase deoxinucleotidil terminal; Mb-1: molécula de imunoglobulina citoplasmática específica para célula B

distribuição celular e funções específicas. Um dos exemplos mais conhecidos da aplicação de marcadores CD se refere à avaliação laboratorial da resistência imunológica em pacientes com AIDS por meio da determinação dos linfócitos CD4 (auxiliar) e CD 8 (citotóxico). Da mesma forma, a determinação do marcador CD 34 tem sido importante na determinação da presença de células progenitoras do sistema hematopoiético em sangue de medula óssea (8). As figuras $1 \mathrm{a}$ e $1 \mathrm{~b}$ mostram a expressão dos antígenos de superfície durante a maturação dos linfócitos T e B.

Entretanto, é com relação aos linfócitos e macrófagos que é possível antever a importância da determinação dos CD para diferenciar subpopulações das importantes células do nosso sistema imunológico, conforme mostra a tabela $2(3,6)$.

Atualmente o uso de anticorpos monoclonais para identificar antígenos de diferenciação celular está sendo aplicado para investigar e caracterizar laboratorialmente a maioria das leucemias agudas e crônicas de origens mielóide e linfóide (Tabela 3).

\section{Citocinas}

Citocinas é o termo genérico empregado para designar um grupo muito extenso de moléculas envolvidas na emissão de sinais entre as células durante o desencadeamento das respostas imunes (figura 2). Todas as citocinas são pequenas proteínas ou peptídeos, algumas contendo moléculas de açúcar ligadas (glicoproteínas). As diferentes citocinas podem ser enquadradas em diversas 
categorias: interferons (IFN), interleucinas (IL), fator estimulador de colônias (CSF), fator de necrose tumoral (TNFa e TNFb), e fator de transformação de crescimento (TGF b).

Os interferons são moléculas proteicas particularmente importantes na limitação da propagação de determinadas infecções virais. Um grupo de interferons (IFN a e IFNb) é produzido por células infectadas por vírus, e um outro grupo (IFN g) é sintetizado por determinadas células ou linfócitos $\mathrm{T}$ ativados. Os interferons induzem um estado de resistência antiviral em células teciduais não infectadas. Os IFN são produzidos na fase inicial da infecção e constituem a primeira linha de resistência a muitas viroses $(3,4)$.

As interleucinas compõem um grande grupo de citocinas denominadas por IL-1 a IL15, produzidas principalmente por células $\mathrm{T}$, embora algumas sejam sintetizadas também por macrófagos e células teciduais. As interleucinas possuem uma variedade de funções, mas a maioria delas está envolvida na indução da divisão de outras células. Cada interleucina atua sobre um grupo limitado e específico de células que expressam receptores adequados para cada interleucina (tabela 4). É importante destacar que a hematopoiese é regulada por mais de uma interleucina. As IL-1 e IL-6 estão envolvidas na ativação do ciclo celular das células-tronco em repouso (ou autorenováveis). A IL-3 está envolvida no crescimento dos precursores das linhagens hemopoiéticas da mesma forma que o fator estimulador de colônias de granulócitos/ macrófagos (GM - CSF). Na medida em que as células se diferenciam, citocinas específicas de linhagens apresentam atividades importantes; a eritropoietina para os eritrócitos, o fator estimulador de colônias de macrófagos (M CSF) para os macrófagos, o fator estimulador de colônias de granulócitos ( $\mathrm{G}-\mathrm{CSF}$ ) para os granulócitos, entre outros $(1,6)$.

Os fatores estimuladores de colônias (CSF) estão diretamente relacionados na divisão e diferenciação das células-tronco na medula óssea, bem como dos precursores dos leucócitos sanguíneos. A quantidade de diferentes CSF é parcialmente responsável pelas proporções dos diferentes tipos celulares que serão produzidos. Alguns CSF também promovem a diferenciação extramedular de células $(3,8)$.

Finalmente outras citocinas além das acima citadas, como são os casos do fator de necrose tumoral - TNFa e TNFb e do fator de transformação de crescimento ( $T G F$ b) que, embora possuem várias funções, são particularmente importantes nas reações inflamatórias e citotóxicas (6).

Nesse contexto específico das citocinas, o futuro da hematologia laboratorial certamente deverá estar direcionada na monitoração quantitativa e na determinação qualitativa das diferentes interleucinas, bem como nas respostas às reações fisiopatológicas causadas por processos inflamatórios e citotóxicos.

\section{Biologia Molecular}

A aplicação cada vez mais abrangente de técnicas de biologia molecular em análises clínicas pode ser resumida por meio do uso de três métodos cientificamente aprovados para este fim: "Southern blotting", Reação em Cadeia da Polimerase ou PCR, e Hibridização "In Situ" por Fluorescência ou FISH.

Southern blotting: Nesta metodologia, o DNA é extraído de células e tratado com enzimas que rompem as ligações químicas entre determinadas bases nitrogenadas da molécula de DNA. Essas enzimas, extraídas de bactérias, são conhecidas por endonucleases de restrição. Os fragmentos da molécula de DNA resultantes do tratamento enzimático são separados (ou fracionados) eletroforeticamente. Entretanto, a separação dos fragmentos de DNA somente poderá ser revelada por meio das suas impressões extraídas do gel de agarose da eletroforese para uma membrana de náilon ou de nitrocelulose, como se fosse um "mata borrão" ou "blotting" (em inglês) e reveladas por sondas radioativas. Essa técnica foi descrita pelo pesquisador E. M. Southern em 1975 , surgindo daí o "Southern blotting". O grande problema atual deste método é o tempo consumido para a revelação dos resultados que chega a ser de aproximadamente uma semana $(1,2,5)$.

Reação em Cadeia da Polimerase PCR: O advento do PCR revolucionou a 
Tabela 4. Sintese e ação das interleucinas

\begin{tabular}{|c|c|c|}
\hline Interceucina & Síntese & Ação \\
\hline IL $-1 \alpha$ & Macrófagos, célula epitelial & $\begin{array}{l}\text { Ativação do linfócito T, células } \\
\text { tronco e Macrófagos. Febre. }\end{array}$ \\
\hline IL $-1 \beta$ & idem & idem \\
\hline IL -2 & Linfócito T & $\begin{array}{l}\text { Proliferação e ativação e linfócito T, } \\
\text { CD } 4, \text { CD } 6 \text { e NL }\end{array}$ \\
\hline $\mathrm{IL}-3$ & $\begin{array}{l}\text { Linfócito T, células tímica } \\
\text { epitelial }\end{array}$ & Início da hematopoiese \\
\hline $\mathrm{IL}-4$ & Linfócito T e mastócito & $\begin{array}{l}\text { Ativação de linfócito B } \\
\text { Diferenciação das CAA }(*)\end{array}$ \\
\hline $\mathrm{IL}-5$ & Linfócito T e mastócito & $\begin{array}{l}\text { Crescimento e diferenciação } \\
\text { de eosinófilos }\end{array}$ \\
\hline $\mathrm{IL}-6$ & Linfócito T e macrófago & $\begin{array}{l}\text { Crescimento e diferenciação de } \\
\text { linfócitos T e B } \\
\text { Produção de proteínas de fase aguda } \\
\text { Ativação das células tronco }\end{array}$ \\
\hline $\mathrm{IL}-7$ & Estroma da medula óssea & Maturação de linfócitos Pré-B e Pré-T \\
\hline $\mathrm{IL}-8$ & Macrófago & $\begin{array}{l}\text { Quimiotáticos para neutrófilos } \\
\text { e linfócito T }\end{array}$ \\
\hline $\mathrm{IL}-9$ & Linfócito T & Ativação dos mastócitos \\
\hline $\mathrm{IL}-10$ & $\begin{array}{l}\text { Linfócito T, macrófago, vírus } \\
\text { Epstein-Barr }\end{array}$ & $\begin{array}{l}\text { Supressor das funções dos macrófagos. } \\
\text { Ativação de linfócito B }\end{array}$ \\
\hline $\mathrm{IL}-11$ & $\begin{array}{l}\text { Fibroblasto do estroma } \\
\text { Medular }\end{array}$ & $\begin{array}{l}\text { Sinergia com IL-3 e IL-4 na } \\
\text { hematopoiese }\end{array}$ \\
\hline $\mathrm{IL}-12$ & Linfócito B e macrófago & $\begin{array}{l}\text { Ativa células NK e induz diferenciação } \\
\text { da célula } \\
\text { T CD4 em célula T h1 }\end{array}$ \\
\hline $\mathrm{IL}-13$ & Linfócito T & $\begin{array}{l}\text { Crescimento e diferenciação de } \\
\text { linfócito B inibe ação de macrófagos }\end{array}$ \\
\hline $\mathrm{IL}-14$ & Linfócito T, alguns linfócitos B & $\begin{array}{l}\text { Fator de crescimento para células B. } \\
\text { Inibe a síntese de Ig. }\end{array}$ \\
\hline $\mathrm{IL}-15$ & Linfócito T & $\begin{array}{l}\text { Ativa células NK, células T NK, CD } 8^{+}, \\
\mathrm{CD} 4^{+} \text {, linfócito B, macrófagos e } \\
\text { células T intestinais } \gamma_{\mathrm{e}} \delta\end{array}$ \\
\hline
\end{tabular}




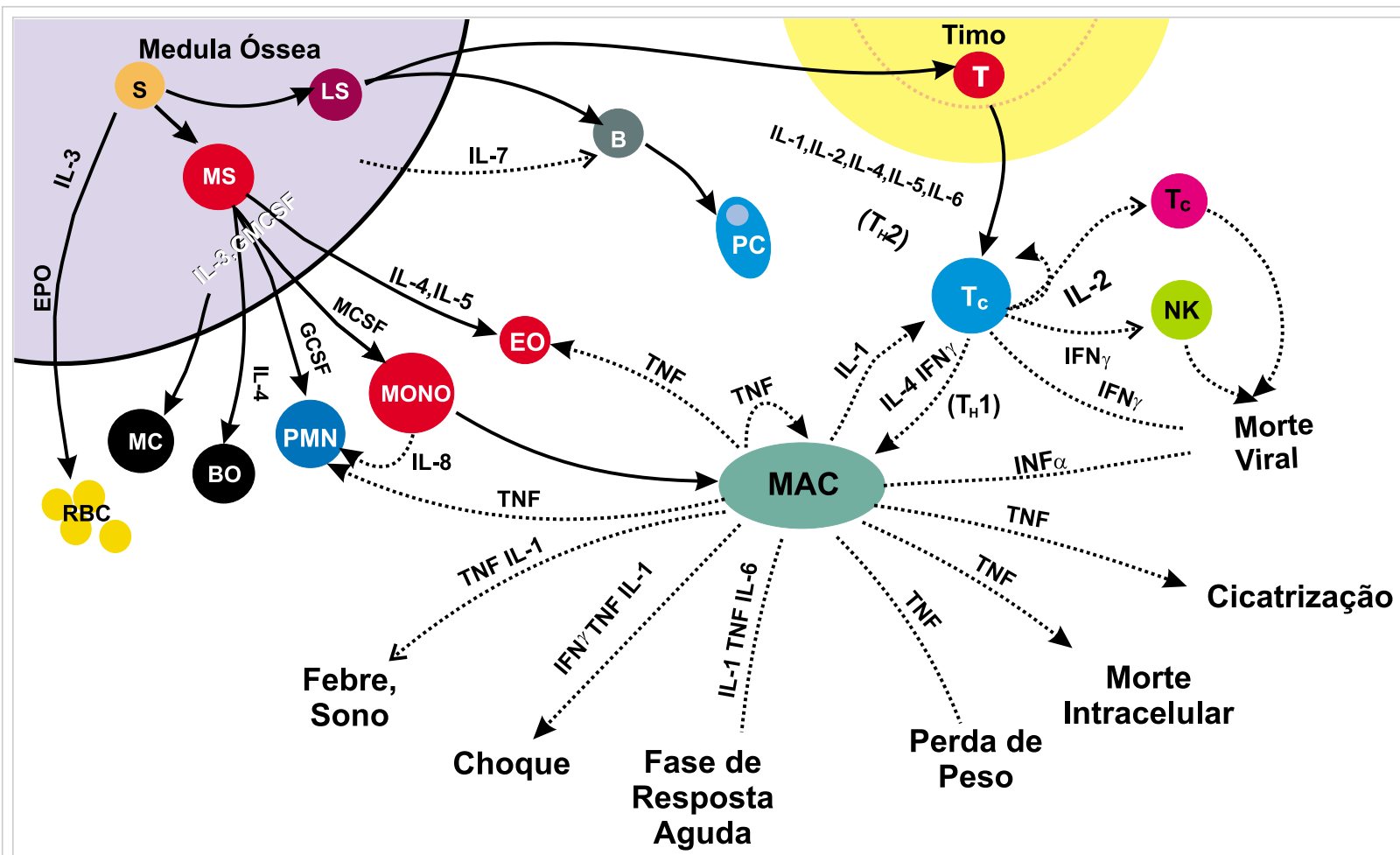

Figura 2. Reação em cadeia do estímulo de Citicinas

S: célula tronco: LS: célula tronco linfóide; MS: célula tronco mielóide; MAC: macrófago; MC: mastócito; PMN: polimorfonucleares; BO: basófilo; EO: eosinófilo; PC: plasmócito; Tc: linfócito T citotóxico; IL: interleucina; TNF: fator de necrose tumoral; MCSF: fator de estímulo de colônicas de granulócito, GCSF: fator de estímulo de colônias de macrófagos; EPO: eritropoietina; Th: linfócito T auxiliar; RGC; eritrócitos

tecnologia molecular em muitas especialidades médicas. Seu uso laboratorial teve grande progresso devido à simplicidade técnica e à rapidez em se obter os resultados. A técnica do PCR é um processo rápido de replicação seletiva de um determinado trecho do DNA genômico "in vitro". A replicação se faz por etapas, tal como se segue:

a) Após a extração do DNA seleciona-se o trecho que se deseja reproduzir ou amplificar até obter a quantidade suficiente para análise;

b) Com drogas específicas desnatura-se a dupla hélice do DNA, separando-a em duas fitas simples e correspondentes de bases nitrogenadas;

c) Com o uso da DNA polimerase (obtido da bactéria Thermus aquaticus - Taq polimerase) submetida a condições específicas de tempo e temperatura (ou ciclos), cada fita simples se duplica em duas novas moléculas de DNA; e este processo é repetido em número suficiente de vezes para obter a quantidade necessária para análise, cerca de um milhão de cópias do original.

Os produtos obtidos pela técnica do PCR podem ser analisados por várias técnicas suplementares das quais a mais comum é a eletroforese em gel de agarose. Uma variação do PCR é o PCR-transcriptase reversa ou RTPCR, que usa o RNA extraído da amostra que se deseja analisar e dele se faz cópias de DNA. O DNA copiado é posteriormente replicado conforme exposição acima. O RTPCR é particularmente usado para análises de translocações cromossômicas (5).

Hibridização “in situ” por fluorescência - FISH: A técnica de FISH se resume na detecção de sequências específicas de DNA ou RNA diretamente nos 
cromossomos de células previamente isoladas para este fim. A análise é realizada em microscópio por meio da geração de um sinal brilhante e colorido nos núcleos das células em metafase e interfase. A FISH é particularmente útil na demonstração de monossomias ou trissomias cromossômicas, bem como nas translocações - notadamente para a identificação da leucemia mielóide crônica - e também na detecção de deleções e amplificações de genes específicos (4).

Aplicação da biologia molecular em hematologia: As aplicações da tecnologia molecular em hematologia poderão elucidar o conhecimento das alterações moleculares de doenças, tal como ocorre atualmente na caracterização das lesões do gene da globina beta nas talassemias do tipo beta e na identificação dos haplótipos da Hb S. Entre as técnicas de biologia molecular, O PCR revolucionou as tendências de aplicabilidade da biologia molecular, não somente pela sua simplicidade, mas pelo rápido diagnóstico de doenças infecciosas, na detecção de doença residual mínima em diversas malignidades hematológicas onde se conhece o defeito molecular, e notadamente na detecção de portadores e no diagnóstico pré-natal de hemofilias e anemias hereditárias. Finalmente, os objetivos mais profundos das aplicações dos conhecimentos de biologia molecular se direcionam na clonagem e sequenciamento de genes para identificar, caracterizar e manipular os gene responsáveis por doenças e produtos tóxicos específicos $(1,5)$.

\section{Technological advances in laboratorial haematology}

\section{Paulo C. Naoum}

\section{Abstract}

Recent progress towards the identification of products synthesised by some blood cells (ex.: cytokines, interleukins, interferons, etc) as well as the identification of white blood cell and stem cell membrane antigens, has aided the exceptional development of laboratory diagnostics of several haematological diseases. In addition to this there has been a great development in the use of molecular biology techniques which have become instrumentals of high definition in the diagnosis and prevention of haematological diseases, specifically those of hereditary origin. This article has the aim of disclosing the main applications of the new technologies that will soon be used widely in laboratory haematology.

Rev.bras.hematol.hemoter., 2001, 23(2):

Key words: Haematology, molecular biology, cytokines

\section{Referências Bibliográficas}

1. Fielding A.K., Ager S., Russell S.J. The future of haematology, molecular biology, and gene therapy. In: ABC of Clinical Haematology, edited by Drew Provan and Andrew Henson. BMJ Publishing Group, London, 1998.

2. Hoffbrand A.V., Lewis S.M., Tuddenham E.G.D. Postgraduate Haematology, $4^{\text {th }}$ ed.

Buttenworth-Heinemann Publishers, 1999.

3. Janeway Jr C.A., Travers P. Imunobiologia. Editora Artes Médicas, Porto Alegre, 1997.

4. Playfair J.H.L., Lydyard P.M. Medical immunology, $2^{n d '}$. Ed. Churchill Livingstone Publ., Endinburgh, 2000.

5. Provan D., Gribben J. Molecular haematology. Blackwell Sciences Ltd, Oxford, 2000.

6. Roitt I., Brostoff J., Male D. Imunologia. Editora Manole Ltda, São Paulo, 1997.

7. Stiene-Martin A.E., Lotspeich-Steininger C.A., Koepke J.A. Clinical Haematology. Lippincott-Raven Publishers, Philadelphia, 1998.

8. Todryk S. Roads that lead to tumour immunotherapy? Mod. Asp. Immunobiol., 2000; 1: 114-118.

Recebido: 23/05/01

Aceito: 30/06/01 